\title{
Hydro-climatic variation drives the long-term ecological evolution of neotropical floodplain lakes: an example from the Magdalena River system, Colombia
}

\author{
Laura Lopera-Congote ${ }^{1}$, Jorge Salgado-Bonnet ${ }^{2}$, Maria Vélez $^{3}$, Andres Link ${ }^{1}$, and Catalina \\ González $^{1}$ \\ ${ }^{1}$ Universidad de los Andes Departamento de Ciencias Biologicas \\ ${ }^{2}$ University of Nottingham \\ ${ }^{3}$ University of Regina
}

October 9, 2020

\begin{abstract}
The Magdalena River in Colombia and its floodplain lakes are key ecosystems for the subsistence of Colombian society. Yet, hydrologic regulation, pollution, deforestation and climate change are threatening its ecological integrity. To understand how these floodplain lakes respond over decadal-centennial scales to natural and anthropogenic stressors, we selected two shallow lakes with varying degree of connectivity to the River and assessed their historical ecological and limnological change through a multi-proxy analysis of diatoms, geochemistry and lake's morphometric variation resulting from extreme periods of high floods and droughts. The reconstruction of the more isolated San Juana Lake covered the last c.500 years. It showed riverineflooded conditions from c.1555-1741 characterised by high detrital inputs, reductive conditions, and dominance of planktonic diatoms. From c.1758-1954, the riverine meander became disconnected, conveying into a marsh-like environment rich in aerophil diatoms and organic matter. The current lake was then formed around the mid 1960s and a diverse lake-associated diatom flora developed. Lake waters became more oxygenated, while sedimentation and nutrients increased through time since the lake formation. The reconstruction for Barbacoas Lake, a waterbody directly connected to the Magdalena River, spanned the last 60 years and showed alternating riverine-wetland-lake conditions dominated by planktonic and benthic diatoms respectively. An exception was however observed, during a prolonged period of low rainfall between 1989-1992, where the lake almost desiccated and where aerophil diatoms prevailed. Inferences of flood magnitudes and river connectivity in the lakes were supported by parallel increases in $\mathrm{Zr} / \mathrm{Fe}$ (flooding) and detrital inputs ( $\mathrm{Ti} / \mathrm{Ca}$ ) along with decreases in sedimentary OM. We proposed that lake hydrological connectivity to the Magdalena River is a main factor controlling lake long-term responses to human pressures. Highly connected lakes may respond more acutely to ENSO events while isolated lakes might be more sensitive to local land-use changes.
\end{abstract}

\section{Hosted file}

Lopera_eta_Flood-plains_Ecol_Evol.pdf available at https://authorea.com/users/365934/ articles/485847-hydro-climatic-variation-drives-the-long-term-ecological-evolutionof-neotropical-floodplain-lakes-an-example-from-the-magdalena-river-system-colombia

\section{Hosted file}

Fig.1_map.eps available at https://authorea.com/users/365934/articles/485847-hydro-climaticvariation-drives-the-long-term-ecological-evolution-of-neotropical-floodplain-lakes-anexample-from-the-magdalena-river-system-colombia 

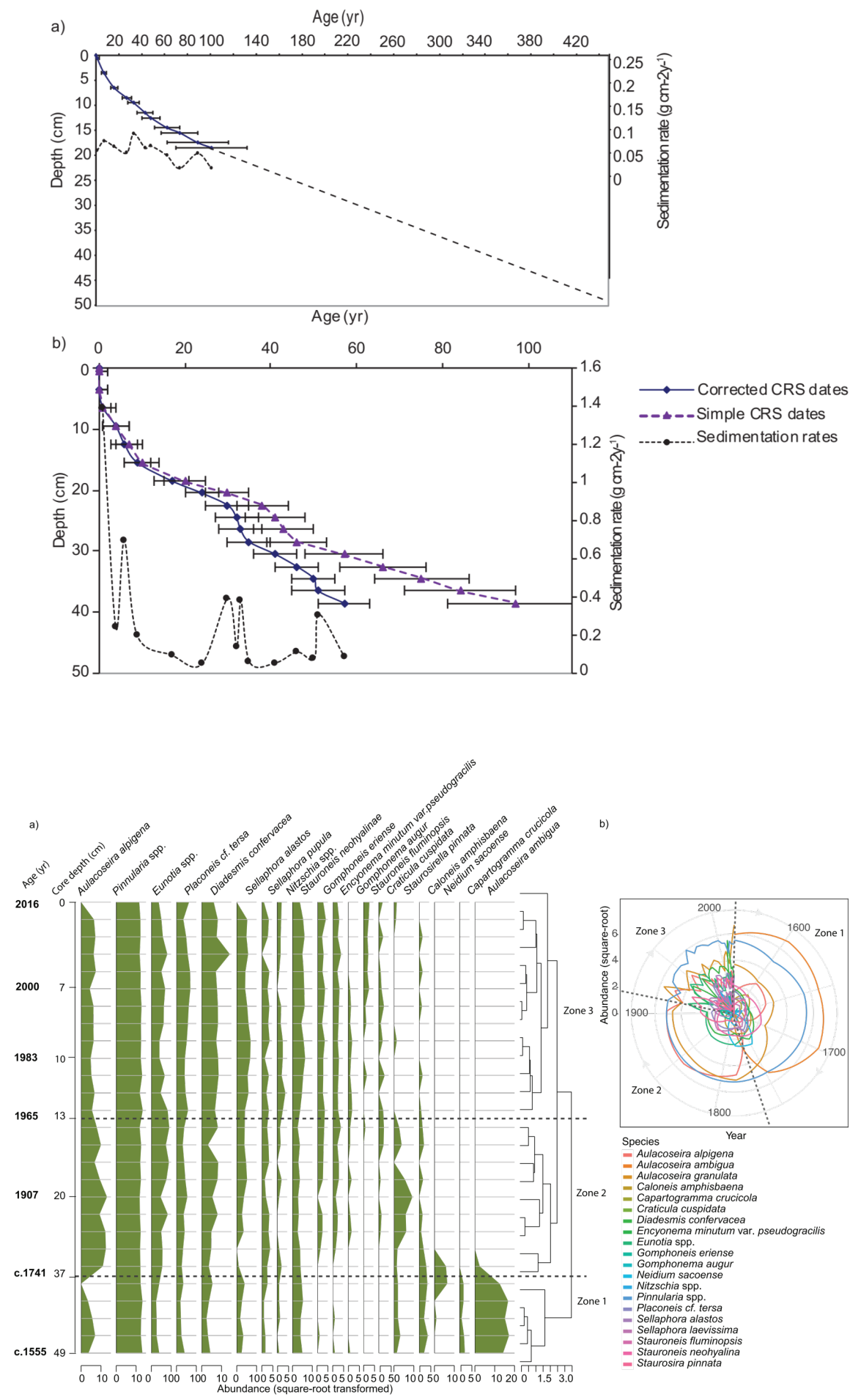


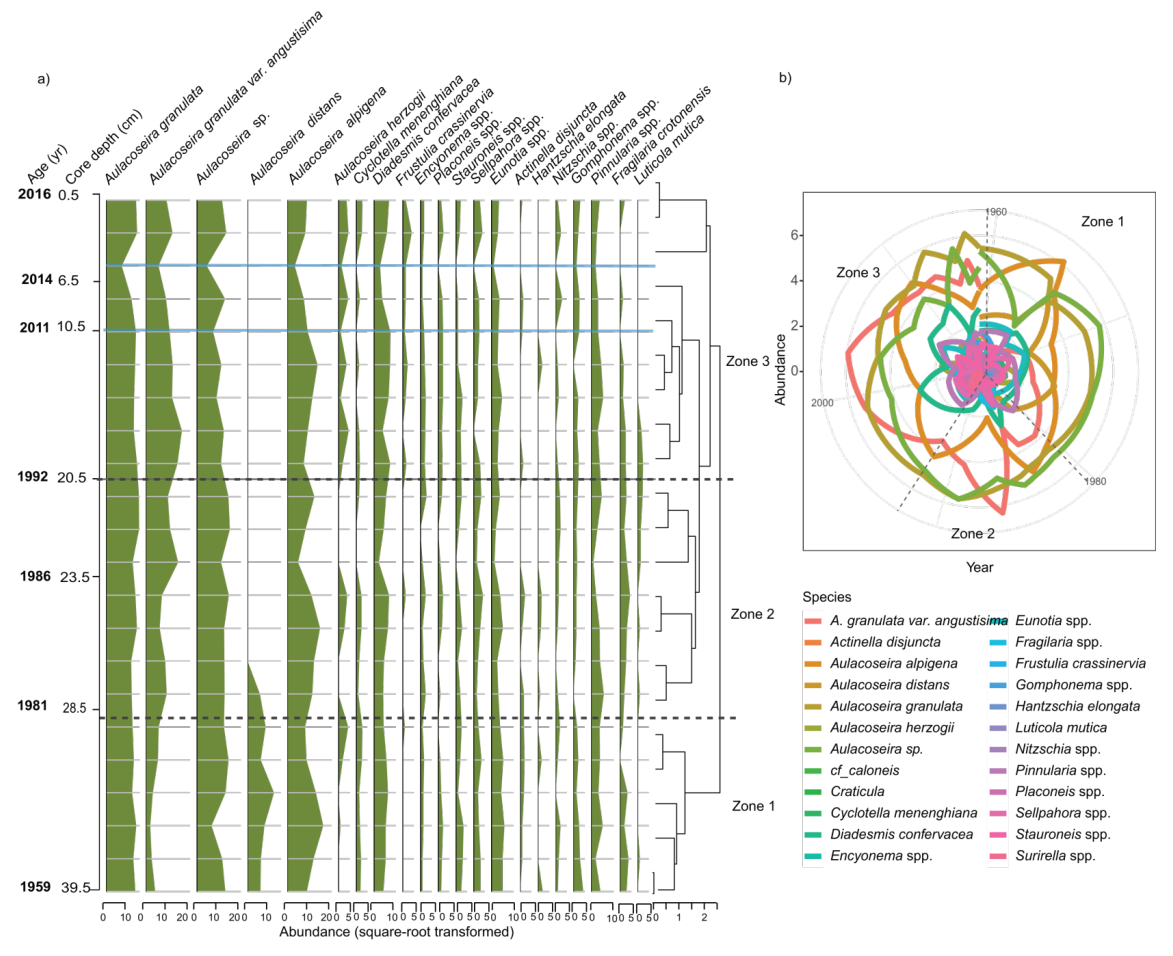

\section{Hosted file}

Fig._5_spei.eps available at https://authorea.com/users/365934/articles/485847-hydroclimatic-variation-drives-the-long-term-ecological-evolution-of-neotropical-floodplainlakes-an-example-from-the-magdalena-river-system-colombia
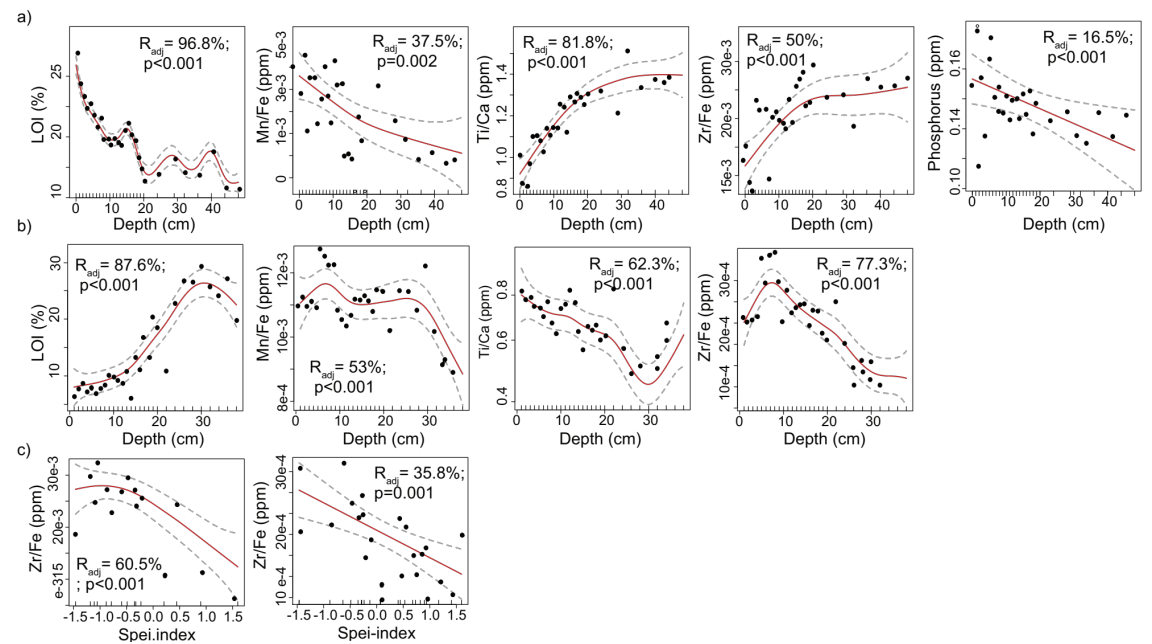

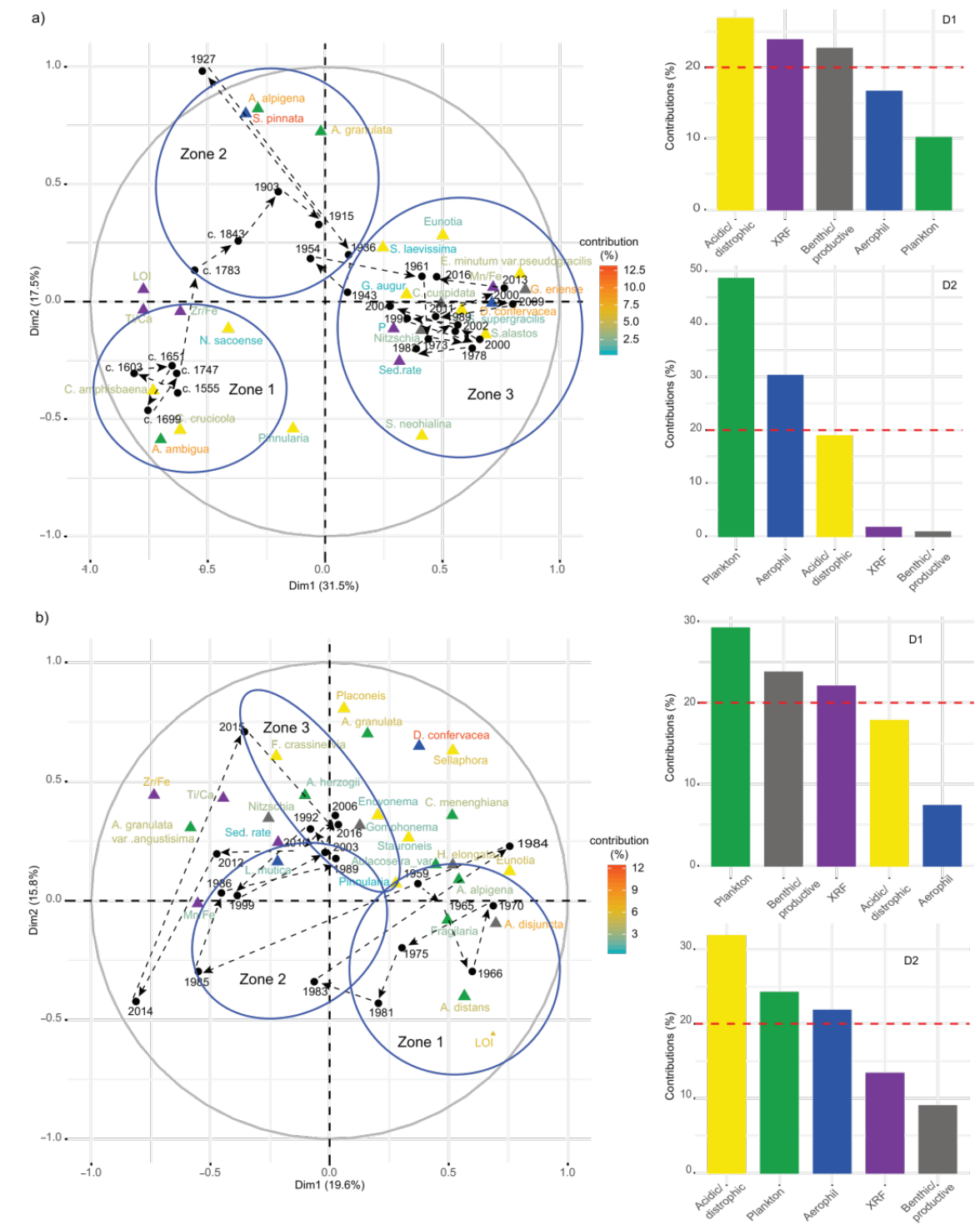